Ten years ago the Kissimmee river in Florida was straightened and canalised, reducing its length from 102 miles to 58 and draining the 40,000 acres of marsh through which it flowed, at a cost of $35 \mathrm{~m}$ dollars. Now the authorities that did the job are

How to put back a

River's Bends having to consider seriously how to undo their work and restore the status quo-at vastly greater expense. The object was to control floods. What has been achieved is a serious pollution problem. The Kissimmee flows into Lake Okeechobee, the main water reservoir for the increasingly populous Florida coast from Palm Beach to Miami, and also for the swamps of the Everglades National Park. Formerly the river meandered through the marshlands, which supported an abundant wildlife (now gone), and also acted as an immense filter for impurities. Now the water rushes down the canal, unpurified, into the lake. The figure of $\$ 88 \mathrm{~m}$ is quoted as the cost of restoring the river, but first the land has to be repurchased, and land values on the drained marshland, some of it now developed or used for cattle, have soared; the former 'worthless' marshland now sells at $\$ 4000$ an acre. Moreover, hydrologists are not agreed that the task can be done at all. A moral tale indeed, but not the first of its kind-or likely to be the last.

\title{
FPS and the Pet Trade
}

At a recent meeting the FPS Council considered the policy on the pet trade declared by IUCN/WWF. This policy supports legislation to ensure that trade in wild creatures for use as pets will be restricted to those which meet the following conditions:

(1) are sufficiently numerous in the wild state to permit of such exploitation;

(2) have been shown through experience or controlled tests to be suitable

for use as pets; and

(3) represent no known danger to human or animal health and will not damage the environment if they escape.

Council agreed to support this policy and to work towards the longterm aim of a total prohibition of the sale of wild-caught animals as pets, as a desirable measure, although it was unlikely it could be implemented in the near future. Council further agreed to seek the drawing-up of a code of practice for keepers of wild-caught animals.

\section{Lake Pedder-a Reprieve?}

Release of the water flooding Lake Pedder and a three-year moratorium are recommended by the Minister of the Environment's Committee investigating this hydro-electric scheme in Tasmania-see May Oryx, page 5. Two remarkable statements appear in the report. One, that 'there are national interests involved which would justify the Australian Government in meeting the costs involved in the moratorium or alternative scheme' (up to A\$8 million), and the other that the only real argument against saving the lake is the inability of Tasmania to meet the cost. 